\title{
Combination of Ultrasound and Heat in the Extraction of Chia Seed (Salvia hispanica L.) Mucilage: Impact on Yield and Technological Properties
}

\author{
Wen-Huei Wang, Chun-Ping Lu and Meng-I Kuo *
}

Citation: Wang, W.-H.; Lu, C.-P.; Kuo, M.-I. Combination of Ultrasound and Heat in the Extraction of Chia Seed (Salvia hispanica L.) Mucilage: Impact on Yield and Technological Properties. Processes 2022, 10, 519 https://doi.org/10.3390/pr10030519

Academic Editor: Maria Angela A. Meireles

Received: 2 February 2022

Accepted: 2 March 2022

Published: 5 March 2022

Publisher's Note: MDPI stays neutral with regard to jurisdictional claims in published maps and institutional affiliations.

Copyright: (C) 2022 by the authors. Licensee MDPI, Basel, Switzerland. This article is an open access article distributed under the terms and conditions of the Creative Commons Attribution (CC BY) license (https:// creativecommons.org/licenses/by/ $4.0 /)$.
Department of Food Science, Fu-Jen Catholic University, 510 Zhongzheng Rd., Xinzhuang Dist., New Taipei City 24205, Taiwan; h831204@gmail.com (W.-H.W.); 089984@mail.fju.edu.tw (C.-P.L.)

* Correspondence: 062998@mail.fju.edu.tw

\begin{abstract}
The effect of ultrasound in combination of heat on the extraction yield and technological properties of chia seed mucilage was investigated. Chia seeds were mixed with distilled water at a seed-to-water ratio of 1:30. The dispersion was adjusted to $\mathrm{pH} 9$ and treated either with heat extraction by water bath or with heat/ultrasound extraction by probe-type sonication at $50{ }^{\circ} \mathrm{C}$ and $80^{\circ} \mathrm{C}$ for 30 and $60 \mathrm{~min}$. The yield and technological properties of mucilage samples were evaluated. The heat/ultrasound extraction gave a greater yield of mucilage (6.92-10.52\%) as compared to the heat extraction (1.03-1.86\%). Images obtained from Scanning Electron Microscope (SEM) have shown that during heat/ultrasound extraction, the amount of mucilage fibers on the surface of chia seed decreased with the increased extraction time. Thus, the yield of mucilage prepared with heat/ultrasound extraction for $60 \mathrm{~min}$ was significantly higher than that of mucilage extracted for $30 \mathrm{~min}$. However, the difference between the seed samples treated with heat/ultrasound extraction at different temperatures was not apparent. The mucilage prepared with heat/ultrasound extraction at $50{ }^{\circ} \mathrm{C}$ for $60 \mathrm{~min}$ had the best technological properties. The amount of protein in the heat/ultrasound extracted mucilage diversified its technological property. Moreover, the mixture of mucilage and whey protein isolate had better miscibility. This study confirms the great potential of application of ultrasound in combination with heat in the extraction of chia seed mucilage.
\end{abstract}

Keywords: chia seed; mucilage; heat; ultrasound; extraction; technological property

\section{Introduction}

Chia (Salvia hispanica L.) is an annual herbaceous plant that grows in arid or semiarid climates. The plant produces numerous small seeds that mature in autumn [1]. Chia seed is composed of $15-25 \%$ protein, 30-33\% lipid, $26-41 \%$ carbohydrate, and $4-5 \%$ ash [1,2]. It also contains high amounts of natural antioxidants and dietary fiber and is an important source of omega-3 fatty acids, vitamin B, and minerals [1,3]. Recently, chia seed has regained popularity due to its health-promoting properties, such as lowering blood sugar levels and improving the cardiovascular system, immune defense system, and gastrointestinal system [1,3-5].

Chia seed mucilage is a water-soluble anionic heteropolysaccharide with high molecular weight (800-2000 kDa) and is a good source of soluble fiber [6]. Chia seed mucilage also possesses excellent water-holding capacity, oil-holding capacity, emulsifying ability, and stabilizing property. The flow behavior of chia seed mucilage is shear thinning type [6-8]. The above technological properties of chia seed mucilage enable wide potential for use in various applications in food industrial. According to Muñoz et al. [9], the mucilages are located in the outer three layers of chia seed coat. These mucilages are exuded from the chia seeds and form a transparent capsule attached to the seed when they are immersed in water. However, chia seed mucilages are not easily separated from the seed coat, making its extraction difficult. 
Various methods have been developed for the extraction of chia seed mucilage. The extraction conditions, such as temperature, time, seed:water ratio, $\mathrm{pH}$, and ionic strength, have significant effects on the yield, purity, and functional properties of the extracted mucilage [9-11]. Generally, the first step of extraction is the hydration and exudation of chia seed mucilage in an aqueous medium, while the separation of mucilage from the seeds involves diverse technological alternatives. Some methods show that the mucilage is separated from the seeds by strong stirring with sand, centrifugation, or vacuum filtration, followed by drying [6,12-14], whereas other methods dehydrate the mucilaginous liquid by applying different drying techniques and then removing the dried mucilage by rubbing it over a sieve [8-11,15]. Furthermore, there is one patent referring to extraction of chia seed mucilage with an ultrasonic bath and high-pressure filtration [16]. However, this method is time-consuming and does not provide information on the properties of the extracted mucilage. Since an ultrasonic bath provides much lower energy intensity, the horn-type ultrasonic device might be an alternative to assist the chia seed mucilage extraction [17]. Therefore, this research attempted to combine the horn-type ultrasonic treatment and the heat treatment in the extraction of chia seed mucilage, and to study the impact of the above processes on the yield and technological properties of chia seed mucilage.

\section{Materials and Methods}

\subsection{Materials}

Chia seeds (Salvia hispanica L.) were obtained from Texture Maker Enterprise Co., Ltd. (New Taipei city, Taiwan). They were stored in a freezer at $-5{ }^{\circ} \mathrm{C}$ before the experiment. Soybean protein isolate (SPI), whey protein isolate (WPI), and sodium caseinate (Nacaseinate) were purchased from Yih Yuan Food Co., Ltd. (New Taipei City, Taiwan). Xanthan gum was provided by Chen Ding Enterprises Co., Ltd. (Taipei City, Taiwan).

\subsection{Extraction and Purification of Chia Seed Mucilage}

The extraction of chia seed mucilage was conducted according to Muñoz et al. [9] and Campos et al. [11] with modification. Chia seeds were mixed with distilled water at a seed-to-water ratio of 1:30 (w/w). The dispersion was adjusted to $\mathrm{pH} 9$ with $0.1 \mathrm{~N} \mathrm{NaOH}$ and treated either with heat by using a water bath (B602, Firstek Scientific Co., Ltd., New Taipei City, Taiwan) at $50{ }^{\circ} \mathrm{C}$ and $80{ }^{\circ} \mathrm{C}$ for 30 and $60 \mathrm{~min}$ or with the heat/ultrasound combination by using a probe-type sonication (S-450D, Branson Ultrasonics Co., Danbury, USA) (400 W power, $5000 \mathrm{~W} / \mathrm{cm}^{2}$ ultrasonic intensity, $20 \mathrm{kHz}$ frequency, $40 \%$ amplitude, $1 \mathrm{~s}$ on $/ 1 \mathrm{~s}$ off). In addition, the proteinase was added to the supernatant at $40{ }^{\circ} \mathrm{C}$ after extraction and separation of the residues to hydrolyze the chia seed protein in mucilage, and then the $95 \%$ ethanol was used to precipitate the purified mucilage [18]. The mucilage was freeze-dried, ground, and passed through a 16-mesh $(1.19 \mathrm{~mm})$ screen to obtain the powder. All preparations were performed in triplicate. The yield of chia seed mucilage was calculated as follows:

$$
\text { Yield }(\%)=\frac{\text { Weight of chia seed mucilage powder }}{\text { Weight of chia seed }} \times 100 \%
$$

\subsection{Scanning Electron Microscopy (SEM) Analysis of Chia Seed}

A table top scanning electron microscope (TM-3000, Hitachi High Technologies Co., Tokyo, Japan) was used to examine the changes of chia seed during the extraction of mucilage. The treated samples were lyophilized. Thereafter, the samples were placed on an aluminum stub and fixed by using double-sided adhesive carbon-tapes. The samples were then sputter-coated with gold. The voltage of microscope was operated at $15 \mathrm{kV}$ for observation.

\subsection{Color Analysis}

The color of mucilage powders was determined using a colorimeter (SP60, X-Rite, Inc., Grand Rapids, MI, USA). The device was calibrated with black and white tiles before 
analyzing. The results were reported in CIELAB color scales, $\mathrm{L}^{*}$ (lightness), $\mathrm{a}^{*}$ (green-red), and $b^{*}$ (yellow-blue). All determinations were performed in triplicate.

\subsection{Proximal Composition}

The moisture, protein, and ash contents of chia seed mucilage were determined according to the AOAC standard methods [19]. Moisture content was measured by oven (RHDM452, Hong Sheng Instruments Co., Ltd., Taipei City, Taiwan) drying at $100 \pm 2{ }^{\circ} \mathrm{C}$. Results were expressed as $\mathrm{g}$ of moisture per $100 \mathrm{~g}$ of sample. Protein content was evaluated by the micor-Kjeldahl method (Digestor TM2508 and Kjeltec TM8100, Foss, Hilleroed, Denmark) with conversion factor of 5.55. The results were expressed as g of protein per $100 \mathrm{~g}$ of dried matter. Ash content was performed by ashing the sample in a furnace (HF202, Today's Instruments Co., Ltd., New Taipei City, Taiwan) at $525^{\circ} \mathrm{C}$. The results were expressed as $\mathrm{g}$ of ash per $100 \mathrm{~g}$ of dried matter. Lipid content was determined by extraction (HT1043 Extraction Unit, Foss, Hilleroed, Denmark) with petroleum ether according to the national standards of Taiwan [20]. The results were expressed as $\mathrm{g}$ of lipid per $100 \mathrm{~g}$ of dried matter. All determinations were conducted in triplicate.

\subsection{Solubility}

The solubility of chia seed mucilage was determined according to the method of Timilsena et al. [8] with slight modification. The sample of $0.06 \mathrm{~g}$ was dispersed in $20 \mathrm{~mL}$ distilled water at different $\mathrm{pH}$ values (5.0, 7.0, and 9.0) and stirred for $60 \mathrm{~min}$ (PC-420D, Coring, Inc., New York, NY, USA). These dispersions were then centrifuged at 10,000 $\times g$ for 15 min (2K15, Sigma Laborzentrifugen $\mathrm{GmbH}$, Osterode am Harz, Germany). The supernatant was collected and dried in an oven at $120{ }^{\circ} \mathrm{C}$ to a constant weight. All determinations were conducted in triplicate. The solubility (\%) of the sample was calculated as follows:

$$
\text { Solubility }(\%)=\frac{\text { Weight of soluble mucilage }}{\text { Sample weight }} \times 100 \%
$$

\subsection{Water Holding Capacity and Oil Holding Capacity}

The water holding capacity (WHC) and oil holding capacity (OHC) of chia seed mucilage were determined according to the method by Timilsena et al. [8] and Coorey et al. [12] with slight modification. The sample of $0.25 \mathrm{~g}$ was weighed in a centrifuge tube to which $10 \mathrm{~g}$ distilled water or $10 \mathrm{~g}$ soybean oil was added. It was stirred for $120 \mathrm{~min}$ at ambient temperature for complete absorption. The resulting mixture was then centrifuged at $2000 \times g$ for $10 \mathrm{~min}$. The supernatant was discarded, and the precipitate weighed. All determinations were conducted in triplicate. The WHC and OHC were calculated as follows:

$$
\begin{gathered}
\text { WHC }(\mathrm{g} / \mathrm{g})=\frac{\text { Sample weight after water absorption }- \text { Sample weight before water absorption }}{\text { Sample weight before water absorption }} \\
\text { OHC }(\mathrm{g} / \mathrm{g})=\frac{\text { Sample weight after oil absorption }- \text { Sample weight before oil absorption }}{\text { Sample weight before oil absorption }}
\end{gathered}
$$

\subsection{Emulsifying Property}

The emulsifying properties of the emulsifying agent are usually expressed in two parameters: emulsifying ability and emulsifying stability index (ESI). Emulsifying ability measures the ability of the emulsifying agent to form am oil-in-water dispersion whereas ESI measures the stability of the emulsion over time [8]. The concentration of $0.1 \%, 0.2 \%$, $0.4 \%$, and $0.8 \%$ of chia seed mucilage solution was emulsified with $1 \%$ soybean oil. The emulsions were prepared by homogenizing mixture at 15,000 rpm for 5 min using a homogenizer (Polytron PT-MR 3000, Kinematica, Switzerland). An aliquot of sample taken from the emulsion was diluted 50 times with distilled water and vortexed for $1 \mathrm{~min}$. The absorbance of the diluted solution was measured at $500 \mathrm{~nm}$ wavelength using a spectrophotometer (SP-8001, Hong Sheng Instruments Co., Ltd., Taipei City, Taiwan). $\mathrm{A}_{0}$ 
and $A_{t}$ were the absorbance of diluted solution at $t=0$ and after $24 \mathrm{~h}$, respectively. All determinations were performed in triplicate. The emulsifying ability was $\mathrm{A}_{0}$ and ESI was calculated as follows:

$$
\mathrm{ESI}(\text { Hour })=\mathrm{A}_{0} \times \frac{\Delta \mathrm{t}}{\mathrm{A}_{0}-\mathrm{A}_{\mathrm{t}}}
$$

\subsection{Flow Behavior}

A controlled-stress rheometer (AR2000ex, TA instrument, Inc., New Castle, DE, USA) equipped with a concentric cylinder geometry was used to measure the flow behavior of the mucilage samples. Flow curves of sample solutions at concentrations of $0.25 \%, 0.5 \%$, $0.75 \%$, and $1 \%$ were measured with increasing shear rate ranging from 0.02 to $500 \mathrm{~s}^{-1}$ at $25{ }^{\circ} \mathrm{C}[13,21]$. All determinations were performed in triplicate. The experimental data were fitted to the rheological model of Herschel-Bulkley as follows:

$$
\sigma=\sigma_{y}+\mathrm{k} \gamma^{\mathrm{n}}
$$

where $\sigma$ is the shear stress $(\mathrm{Pa}), \sigma_{\mathrm{y}}$ is the yield stress $(\mathrm{Pa}), \mathrm{k}$ is the consistency index $\left(\mathrm{Pa} \cdot \mathrm{s}^{\mathrm{n}}\right)$ $\gamma$ is the shear rate $\left(\mathrm{s}^{-1}\right), \mathrm{n}$ is the flow behavior index.

\subsection{Phase Diagram Construction}

The phase diagram construction of protein and chia seed mucilage mixture was performed according to the method by Kontogiorgos et al. [22] with modification. The $1 \mathrm{M}$ phosphate buffer ( $\mathrm{pH} 7)$ was used to prepare the $5 \%(w / w)$ mucilage solution and the $10-30 \%(w / w)$ protein solutions (SPI, Na-casein, WPI). The mucilage solution and protein solution were mixed at different ratios of 5:95, 20:80, 35:65, 50:50, 65:35, 80:20, and 95:5. These mixtures were centrifuged at $3000 \times g$ at $5{ }^{\circ} \mathrm{C}$ for $30 \mathrm{~min}$ in order to accelerate the equilibrium phase separation. The protein content and polysaccharide content in both supernatant and precipitate were analyzed. The polysaccharide content was measured by the phenol-sulfuric acid method. Xylose and glucose at a ratio of 2:1 was used as a standard for the construction of calibration curve. The protein content was conducted by the Biuret method. The bovine serum albumin (BSA) was used for the construction of the calibration curve. All the samples were analyzed in triplicate. Non-linear regression of the experimental data was performed using Origin software (Version 8.6, OriginLab Corporation, Northampton, MA, USA) to produce the final binodal curve.

\subsection{Statistical Analysis}

Statistical analysis was performed using JMP (SAS Institute, Inc., Cary, NC, USA) software. Analysis of variance (ANOVA) and Tukey's multiple comparisons were carried out in order to test differences at 95\% $(p<0.05)$ significance level.

\section{Results and Discussion}

\subsection{Morphology of Raw and Treated Chia Seed}

Figure 1 shows the morphology of raw chia seed observed by SEM. The chia seed was elliptical shape with about $2 \mathrm{~mm}$ length and $1.2 \mathrm{~mm}$ width (Figure 1A). Its surface was smooth and glabrous (Figure 1B). Our results were similar to those of Ixtaina et al. [23] and Capitani et al. [24].

Figure 2 presents the morphology of chia seeds extracted with different combinations of ultrasound and heat. According to Muñoz et al. [9], mucilage fibers appeared on the surface of the chia seeds right after the seeds came in contact with water. These mucilage fibers spread out slowly until they became fully extended. They were uniformly distributed on the surface around the seed and developed a volcano-shaped columella structure. In our study, the mucilage fibers already surrounded the chia seed surface after extraction for $5 \mathrm{~min}$ at $50{ }^{\circ} \mathrm{C}$ and $80^{\circ} \mathrm{C}$. Moreover, no obvious change was observed on the morphology of treated chia seeds on increasing extraction time. We also observed that there were more mucilage fibers spread out on the surface of $80^{\circ} \mathrm{C}$ treated chia seeds than the $50{ }^{\circ} \mathrm{C}$ treated 
chia seed. However, these mucilage fibers seemed to be strongly attached to the seed and were difficult to separate. The above results indicate that the rate of chia mucilage production was very fast-within several minutes after initial extraction-and it was more pronounced when the extraction temperature was higher. Subsequently, the mucilage fibers gradually surrounded the rest of the seed since the water adsorption of chia seed became slower and gradually reached equilibrium [9,24]; meanwhile, fewer mucilage fibers might have been released into the aqueous solution.
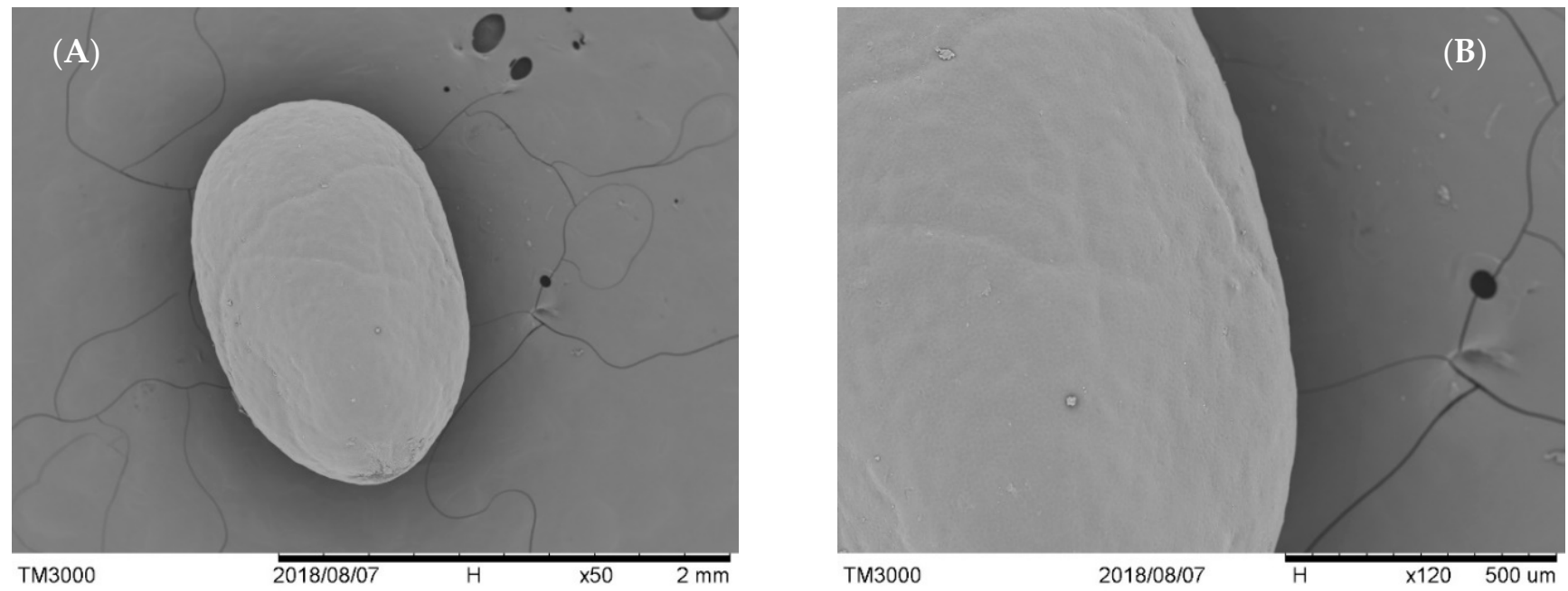

Figure 1. Scanning electron microscopy $($ SEM) images $(\times 120)$ of raw chia seed: $(A)$ Lateral view $(\times 50)$; (B) pericarp surface.

During the combination of heat/ultrasound extraction, the amount of mucilage fibers on the surface of chia seed decreased on increasing the extraction time and the difference between the samples treated at different temperatures was no apparent. According to Zia et al. [25], as the extraction temperature increases up to $70^{\circ} \mathrm{C}$, the viscosity and surface tension of water decrease, which decreases the sonication effect. The above results suggest that during heat/ultrasound extraction, the mucilage fibers were gradually separated from the seed and released to the aqueous solution by the ultrasonic wave.

\subsection{Extraction Yield of Chia Seed Mucilage}

Table 1 presents the yield of chia seed mucilage extracted with different combinations of ultrasound and heat. The yield of chia seed mucilage prepared with heat extraction was between $1.03-1.86 \%$. The yield of mucilage extracted at $80{ }^{\circ} \mathrm{C}$ was significantly higher than that of mucilage extracted at $50{ }^{\circ} \mathrm{C}$, but the extraction time had no significant effect on the yield. According to Orifici et al. [10], the viscosity of mucilage fiber might decrease and its solubility might increase with temperature, resulting in the increase in the mass transfer rate of mucilage fibers. Consequently, these mucilage fibers could be effectively released from the surface of the chia seed. The extraction yield of chia seed mucilage prepared from other studies was 5.5-12.2\% (d.b.) [10] and 4.8-8.7\% [15] at different temperatures and seed/water ratios. However, their processes were time-consuming (more than $2 \mathrm{~h}$ ).

On the other hand, the heat/ultrasound extraction provided a greater yield of mucilage (6.92-10.52\%) compared to the heat extraction. The yield of mucilage prepared with heat/ultrasound extraction for $60 \mathrm{~min}$ was significantly higher than that of mucilage prepared with heat/ultrasound extraction for $30 \mathrm{~min}$. However, the temperature of heat/ultrasound extraction had no significant effect on the yield. Ultrasonic wave made the liquid medium produce cavitation bubbles, resulting in internal explosions, which led to macroturbulence, high-velocity inter-particle collisions, and perturbation [26,27]. We thought that the above phenomenon would generate stronger microscopic shearing forces, 
which might drive the separation of the mucilage layers covering the seeds. This isolation process continued with time until the whole mucilage layer was separated.

In addition, the chia seed mucilage prepared with $50{ }^{\circ} \mathrm{C}$ heat/ultrasound extraction for $60 \mathrm{~min}$ was further treated with proteinase to obtain the purified mucilage. The yield of purified mucilage was $2.11 \%$ (Table 1 ). The lower yield of purified mucilage was because of the removal of protein in the mucilage.

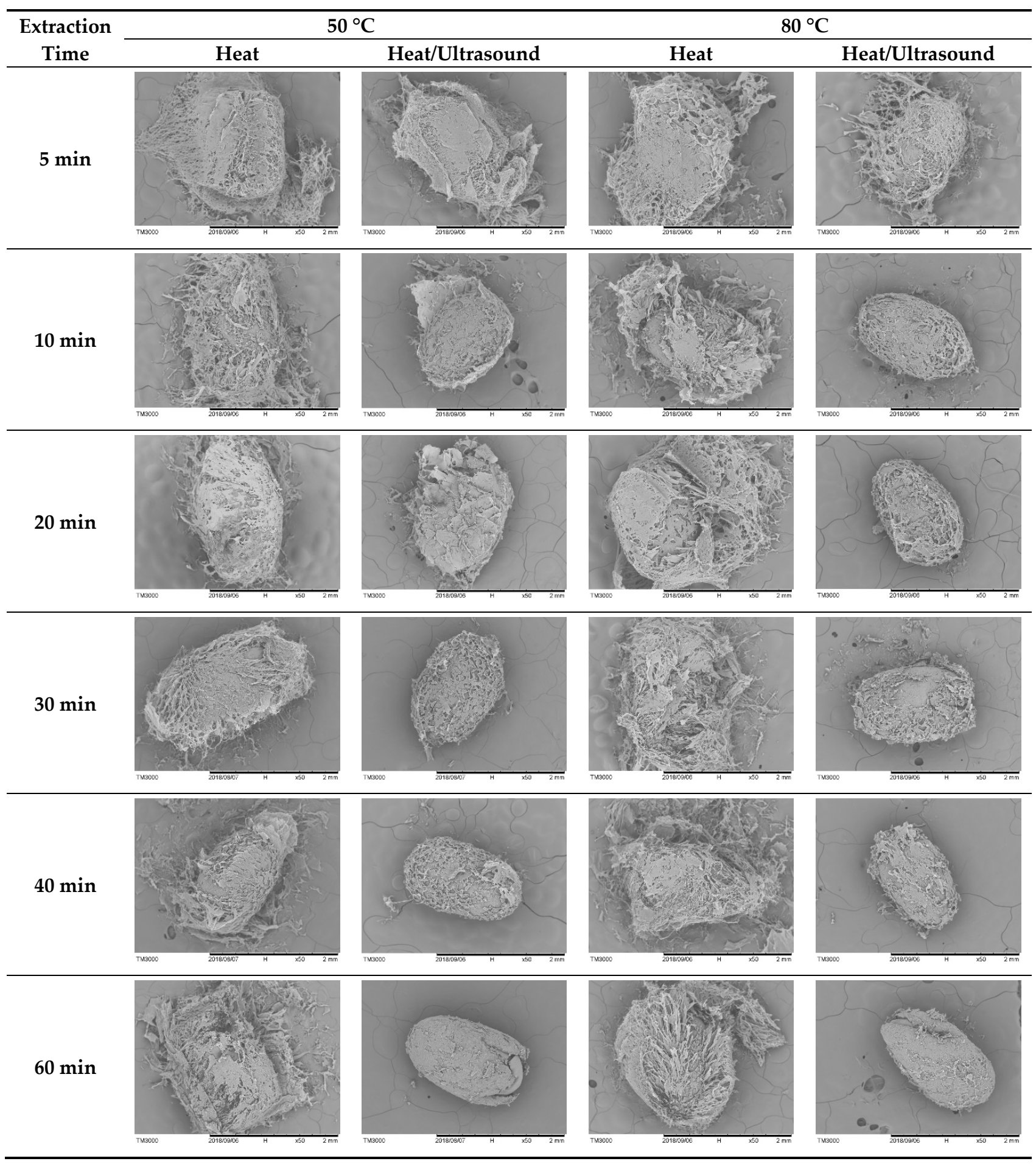

Figure 2. Scanning electron microscopy (SEM) images $(\times 50)$ of chia seeds extracted at $50{ }^{\circ} \mathrm{C}$ and $80^{\circ} \mathrm{C}$ under different conditions. 
Table 1. The yield of chia seed mucilage extracted with different combinations of ultrasound and heat.

\begin{tabular}{|c|c|c|c|}
\hline \multicolumn{2}{|c|}{ Extraction Conditions } & Purification & Yield (\%) \\
\hline \multirow{4}{*}{ Heat } & $50{ }^{\circ} \mathrm{C} / 30 \mathrm{~min}$ & No & $1.03 \pm 0.27^{\mathrm{D}}$ \\
\hline & $50{ }^{\circ} \mathrm{C} / 60 \mathrm{~min}$ & No & $1.09 \pm 0.02^{\mathrm{D}}$ \\
\hline & $80^{\circ} \mathrm{C} / 30 \mathrm{~min}$ & No & $1.79 \pm 0.13^{C}$ \\
\hline & $80^{\circ} \mathrm{C} / 60 \mathrm{~min}$ & No & $1.86 \pm 0.09 \mathrm{C}$ \\
\hline \multirow{5}{*}{ Heat/Ultrasound } & $50^{\circ} \mathrm{C} / 30 \mathrm{~min}$ & No & $6.92 \pm 0.33^{\mathrm{B}}$ \\
\hline & $50{ }^{\circ} \mathrm{C} / 60 \mathrm{~min}$ & No & $10.39 \pm 0.57^{\mathrm{A}}$ \\
\hline & $80^{\circ} \mathrm{C} / 30 \mathrm{~min}$ & No & $6.98 \pm 0.23^{\mathrm{B}}$ \\
\hline & $80^{\circ} \mathrm{C} / 60 \mathrm{~min}$ & No & $10.52 \pm 0.61^{\mathrm{A}}$ \\
\hline & $50^{\circ} \mathrm{C} / 60 \mathrm{~min}$ & Yes & $2.11 \pm 0.07^{C}$ \\
\hline
\end{tabular}

Values are mean \pm standard deviation. Different superscript capital letters within a column indicate significant differences $(p<0.05)$.

\subsection{Appearance and Color of Chia Seed Mucilage}

The appearance of the chia seed mucilage extracted with different combination of ultrasound and heat was demonstrated in Figure 3. The mucilage powders were mostly milky white. These mucilage powders were sieved using a 16-mesh screen, so their particle size was less than $1.19 \mathrm{~mm}$. The appearance of the chia seed mucilage powders prepared with heat extraction was not much different, but that of mucilage powders prepared with heat/ultrasound extraction was slightly darker in color, especially the powder, which was prepared with $80^{\circ} \mathrm{C}$ heat/ultrasound extraction for $60 \mathrm{~min}$. Campos et al. [11] revealed a yellow color mucilage, which was extracted at $40^{\circ} \mathrm{C}$ for $3.6 \mathrm{~h}$.

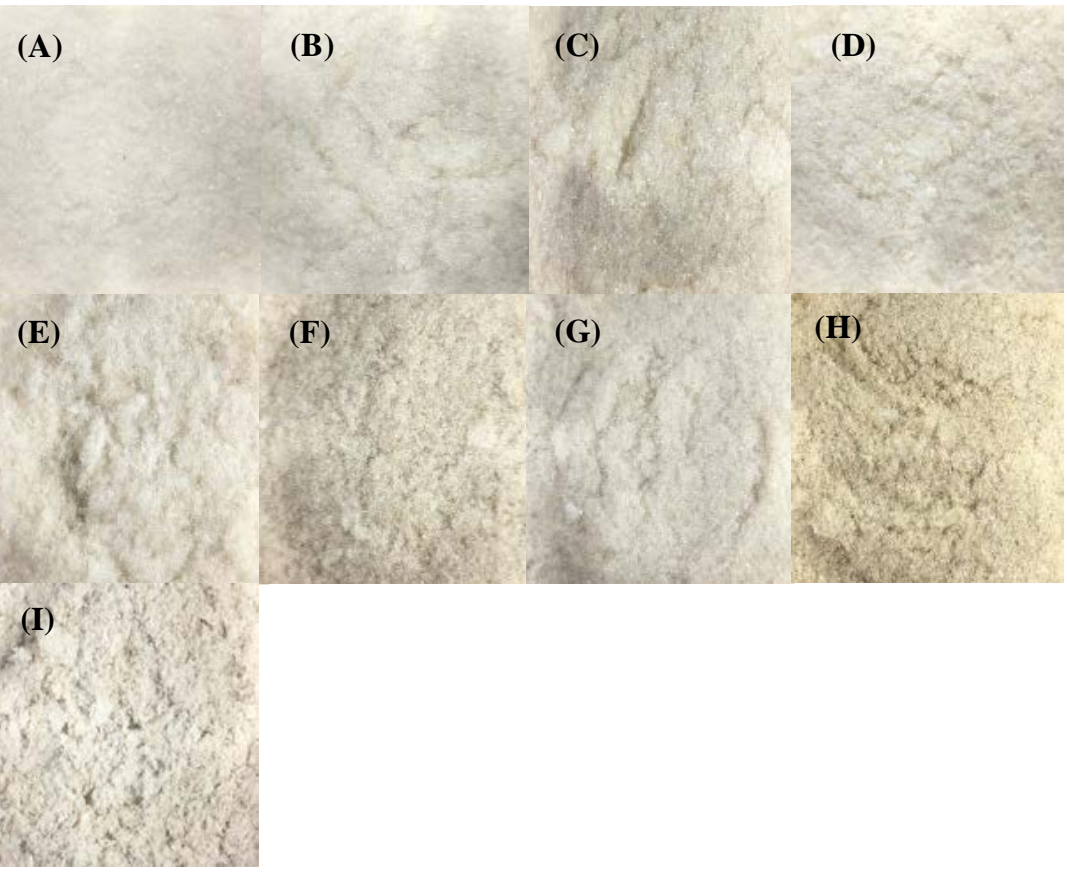

Figure 3. The appearance of chia seed mucilage powders extracted with different combinations of ultrasound and heat. (A) Heat $-50^{\circ} \mathrm{C} / 30 \mathrm{~min}$; (B) Heat-50 ${ }^{\circ} \mathrm{C} / 60 \mathrm{~min}$; (C) Heat- $80{ }^{\circ} \mathrm{C} / 30 \mathrm{~min}$; (D) Heat-80 ${ }^{\circ} \mathrm{C} / 60 \mathrm{~min}$; (E) Heat/Ultrasound-50 ${ }^{\circ} \mathrm{C} / 30 \mathrm{~min}$; (F) Heat/Ultrasound-50 ${ }^{\circ} \mathrm{C} / 60 \mathrm{~min}$; (G) Heat/Ultrasound-80 ${ }^{\circ} \mathrm{C} / 30 \mathrm{~min}$; (H) Heat/Ultrasound- $80{ }^{\circ} \mathrm{C} / 60 \mathrm{~min}$; (I) Heat/Ultrasound$50{ }^{\circ} \mathrm{C} / 60$ min with purification.

Table 2 presents the color of the chia seed mucilage powders extracted with different combinations of ultrasound and heat. $L^{*}$ represents darkness to lightness with values ranging from 0 to 100 . The $L^{*}$ value of heat-extracted mucilage powders was between 30.80 and 41.22 , which decreased significantly on increasing the extraction temperature 
and time. The $\mathrm{L}^{*}$ value of the heat/ultrasound extracted mucilage powders was in the range of 21.23-38.42, which decreased significantly with the extraction temperature and time. Furthermore, the $L^{*}$ value of the heat-extracted mucilage was higher than that of the heat/ultrasound-extracted mucilage.

Table 2. The color of chia seed mucilage powders extracted with different combinations of ultrasound and heat.

\begin{tabular}{|c|c|c|c|c|c|}
\hline Extraction C & onditions & Purification & $\mathbf{L}^{*}$ & $a^{*}$ & $\mathbf{b}^{*}$ \\
\hline \multirow{4}{*}{ Heat } & $50^{\circ} \mathrm{C} / 30 \mathrm{~min}$ & No & $41.22 \pm 0.11^{\mathrm{A}}$ & $1.79 \pm 0.00^{\mathrm{E}}$ & $5.26 \pm 0.02^{G}$ \\
\hline & $50{ }^{\circ} \mathrm{C} / 60 \mathrm{~min}$ & No & $39.91 \pm 0.95 \mathrm{AB}$ & $2.75 \pm 0.02 \mathrm{CD}$ & $5.83 \pm 0.17^{\mathrm{F}}$ \\
\hline & $80{ }^{\circ} \mathrm{C} / 30 \mathrm{~min}$ & No & $32.98 \pm 0.06^{C}$ & $2.59 \pm 0.06^{\mathrm{D}}$ & $9.52 \pm 0.05^{\text {В }}$ \\
\hline & $80{ }^{\circ} \mathrm{C} / 60 \mathrm{~min}$ & No & $30.80 \pm 0.09^{\mathrm{D}}$ & $3.62 \pm 0.06^{\mathrm{B}}$ & $9.64 \pm 0.12^{\mathrm{B}}$ \\
\hline \multirow{5}{*}{ Heat/Ultrasound } & $50{ }^{\circ} \mathrm{C} / 30 \mathrm{~min}$ & No & $38.42 \pm 0.68^{\mathrm{B}}$ & $1.90 \pm 0.03^{\mathrm{E}}$ & $5.77 \pm 0.06^{\mathrm{F}}$ \\
\hline & $50{ }^{\circ} \mathrm{C} / 60 \mathrm{~min}$ & No & $21.78 \pm 0.15^{\mathrm{E}}$ & $2.78 \pm 0.05^{C}$ & $7.07 \pm 0.10^{\mathrm{D}}$ \\
\hline & $80{ }^{\circ} \mathrm{C} / 30 \mathrm{~min}$ & No & $31.08 \pm 0.27^{\mathrm{D}}$ & $2.64 \pm 0.02 \mathrm{CD}$ & $7.56 \pm 0.09^{C}$ \\
\hline & $80{ }^{\circ} \mathrm{C} / 60 \mathrm{~min}$ & No & $21.23 \pm 0.24^{\mathrm{E}}$ & $4.26 \pm 0.02^{\mathrm{A}}$ & $10.85 \pm 0.07^{\mathrm{A}}$ \\
\hline & $50{ }^{\circ} \mathrm{C} / 60 \mathrm{~min}$ & Yes & $21.59 \pm 0.45^{\mathrm{E}}$ & $2.61 \pm 0.10^{C D}$ & $6.60 \pm 0.22^{\mathrm{E}}$ \\
\hline
\end{tabular}

Values are mean \pm standard deviation. Different superscript capital letters within a column indicate significant differences $(p<0.05)$.

The $\mathrm{a}^{*}$ represents greenness to redness with values from -128 to +127 ; and $\mathrm{b}^{*}$ represents blueness to yellowness also with values from -128 to +127 . The $\mathrm{a}^{*}$ value of heat-extracted mucilage powders was between $1.79-3.62$, and the $b^{*}$ value was between 5.26-9.64. Moreover, the $a^{*}$ value of heat/ultrasound-extracted mucilage powders was between 1.90-4.26, and the $b^{*}$ value was between 5.77-10.85. Both $a^{*}$ and $b^{*}$ values of mucilage powders increased significantly with the increase in extraction temperature and time. The $b^{*}$ value of heat-extracted mucilage powders was lower than that of heat/ultrasound extracted mucilage powders. Besides, the purification process of chia seed mucilage did not affect its appearance and color (Figure 3 and Table 2).

The above results indicate that extraction temperature, extraction time, and ultrasonic treatment affected the color of the chia seed mucilage powder. Campos et al. [11] mentioned that the combination of higher extraction temperature and longer extraction time promoted the diffusion of natural pigments or tannic substances from the chia seed to the aqueous solution, leading to darkening of the extracted mucilage powder. In addition, the microscopic shearing forces generated by ultrasonic wave might damage the chia seed coat and more natural pigments could enter the aqueous solution, consequently darkening the heat/ultrasound extracted mucilage powder [26].

\subsection{Proximate Composition of Chia Seed Mucilage}

Table 3 compares the chemical composition of chia seed mucilage powders extracted by ultrasound in combination with heat. All the results, except for moisture content, were expressed on a dry basis. The moisture content of mucilage did not differ statistically between the treatments and it was in the range of 6.83 to $7.10 \%$. The lipid content of mucilage was in the range of 2.68 to $2.79 \%$. The extraction time and temperature did not influence the lipid content of mucilage. The protein and ash contents of mucilage increased significantly with the increase in extraction time and temperature. According to GarcíaSalcedo et al. [28], $\mathrm{Mg}$, P, and Ca were the primarily minerals in the chia seed mucilage. In addition, the carbohydrate content of mucilage decreased significantly with extraction time and temperature. Since the protein and ash content of mucilage was higher when the extraction time and temperature rose, the proportion of carbohydrates was relatively low.

As mentioned above, the microscopic shearing forces generated by ultrasonic wave can damage the chia seed coat, and more protein and ash is released to the aqueous solution as the extraction time increased [26]. Moreover, higher extraction temperature promoted the solvent diffusion rate and increased the solubility of the substances, resulting in more protein and ash being released from the chia seed to the aqueous solution [11]. 
Table 3. The chemical composition of chia seed mucilage powders extracted by ultrasound in combination with heat.

\begin{tabular}{|c|c|c|c|c|c|c|}
\hline \multirow{2}{*}{$\begin{array}{l}\text { Heat/Ultrasound } \\
\text { Extraction Conditions }\end{array}$} & \multirow{2}{*}{ Purification } & \multirow{2}{*}{$\begin{array}{l}\text { Moisture } \\
(\%)\end{array}$} & \multicolumn{4}{|c|}{ Dry Weight Basis (\%) } \\
\hline & & & Protein & Lipid & Ash & Carbohydrate * \\
\hline $50^{\circ} \mathrm{C} / 30 \mathrm{~min}$ & No & $7.10 \pm 0.47^{\mathrm{A}}$ & $5.12 \pm 0.22^{\mathrm{D}}$ & $2.70 \pm 0.10^{\mathrm{A}}$ & $8.73 \pm 0.13^{C}$ & $83.45 \pm 0.27^{\mathrm{A}}$ \\
\hline $50^{\circ} \mathrm{C} / 60 \mathrm{~min}$ & No & $6.83 \pm 0.31^{\mathrm{A}}$ & $5.72 \pm 0.09^{\mathrm{C}}$ & $2.68 \pm 0.09^{\mathrm{A}}$ & $10.07 \pm 0.09^{\mathrm{B}}$ & $81.53 \pm 0.16^{\mathrm{B}}$ \\
\hline $80^{\circ} \mathrm{C} / 30 \mathrm{~min}$ & No & $7.06 \pm 0.64^{\mathrm{A}}$ & $7.91 \pm 0.03^{\mathrm{B}}$ & $2.69 \pm 0.13^{\mathrm{A}}$ & $10.60 \pm 0.26^{\mathrm{AB}}$ & $78.80 \pm 0.29^{C}$ \\
\hline $80^{\circ} \mathrm{C} / 60 \mathrm{~min}$ & No & $6.83 \pm 0.52^{\mathrm{A}}$ & $12.05 \pm 0.15^{\mathrm{A}}$ & $2.79 \pm 0.03 \mathrm{~A}$ & $11.32 \pm 0.47^{\mathrm{A}}$ & $73.84 \pm 0.49^{\mathrm{D}}$ \\
\hline $50^{\circ} \mathrm{C} / 60 \mathrm{~min}$ & Yes & $7.03 \pm 0.08^{\mathrm{A}}$ & $0.72 \pm 0.08^{\mathrm{E}}$ & $1.22 \pm 0.09^{\mathrm{B}}$ & $7.68 \pm 0.06^{\mathrm{D}}$ & $90.38 \pm 0.13^{\mathrm{E}}$ \\
\hline
\end{tabular}

Values are mean \pm standard deviation. Different superscript capital letters within a column indicate significant differences $(p<0.05) .{ }^{*}$ Carbohydrate $=100-$ Protein - Lipid - Ash. Standard deviation of carbohydrate $=\sqrt{a^{2}+b^{2}+c^{2}} \cdot \mathrm{a}=$ Standard deviation of protein. $\mathrm{b}=$ Standard deviation of lipid. $\mathrm{c}=$ Standard deviation of ash

\subsection{Technological Properties of Chia Seed Mucilage 3.5.1. Solubility}

The chia seed mucilage was readily hydrated in water at an ambient temperature, producing a clear solution. Solubility of chia seed mucilage powders extracted by ultrasound in combination with heat at different $\mathrm{pH}$ is presented in Figure 4. The solubility of chia seed mucilage decreased slightly on increasing extraction time and temperature. This might be owed to the decrease of carbohydrate content in mucilage. Furthermore, the solubility of mucilage increased with increasing $\mathrm{pH}$. Timilsena et al. [8] pointed out that chia seed gum showed strong anionic characteristic at alkaline $\mathrm{pH}$ due to the enhanced ionization of the carboxyl groups in uronic acids of gum at higher $\mathrm{pH}$ values. Accordingly, the polysaccharides in chia seed mucilage might disperse well at an alkaline $\mathrm{pH}$ due to electrostatic repulsive forces, resulting in better solubility. In addition, the protein isolated from chia seed was almost completely soluble around $\mathrm{pH} 12.0$ [29], and the soluble protein might contribute to the increase in mucilage solubility at the alkaline $\mathrm{pH}$ as well.

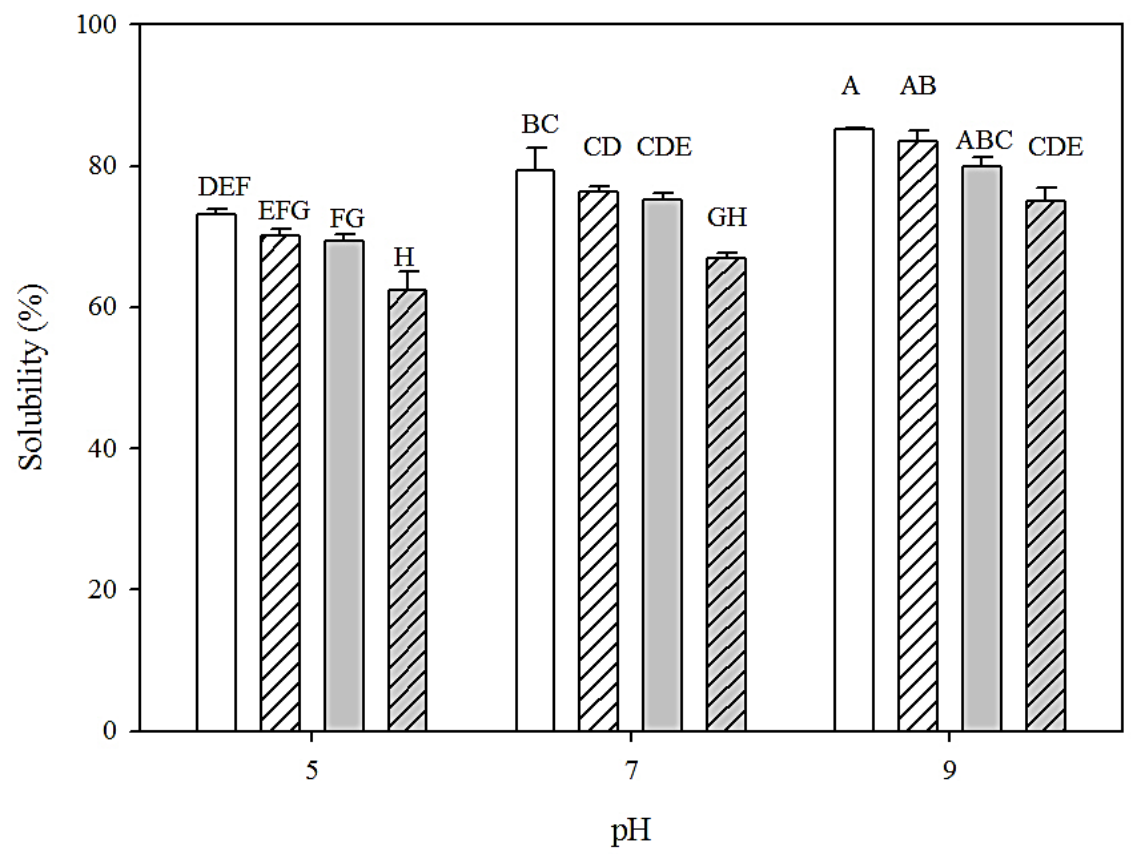

Figure 4. The solubility of chia seed mucilage extracted by ultrasound in combination with heat at different $\mathrm{pH}$. Error bars represent standard deviations. Means with different superscript capital letters denote significant difference $(p<0.05)$. ( $\square$ Heat/Ultrasound-50 ${ }^{\circ} \mathrm{C} / 30 \mathrm{~min}$; $\mathscr{\mathbb { C }}$ Heat/Ultrasound-

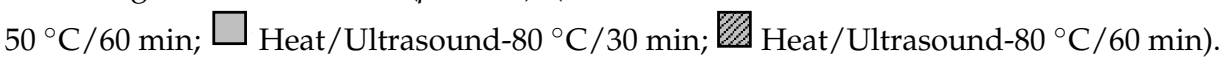




\subsubsection{Water Holding Capacity and Oil Holding Capacity}

Water holding capacity (WHC) is defined as the maximum amount of water that can be absorbed and retained by the hydrated sample under the action of an external force, while oil holding capacity $(\mathrm{OHC})$ is the amount of oil absorber through the nonpolar sites within protein molecules or trapped in the spongy gel structure [12,30]. The WHC and $\mathrm{OHC}$ of chia seed mucilage extracted by ultrasound in combination with heat are shown in Figure 5. The WHC and OHC of chia seed mucilage were in the range of 18.52 to $39.39 \mathrm{~g} / \mathrm{g}$ and 26.23 to $34.31 \mathrm{~g} / \mathrm{g}$, respectively. The chia seed mucilage extracted at $50{ }^{\circ} \mathrm{C}$ for $30 \mathrm{~min}$ had the highest WHC and OHC. The WHC of mucilage decreased with extraction time and temperature, but the $\mathrm{OHC}$ of mucilage treated with other extraction conditions did not differ significantly.

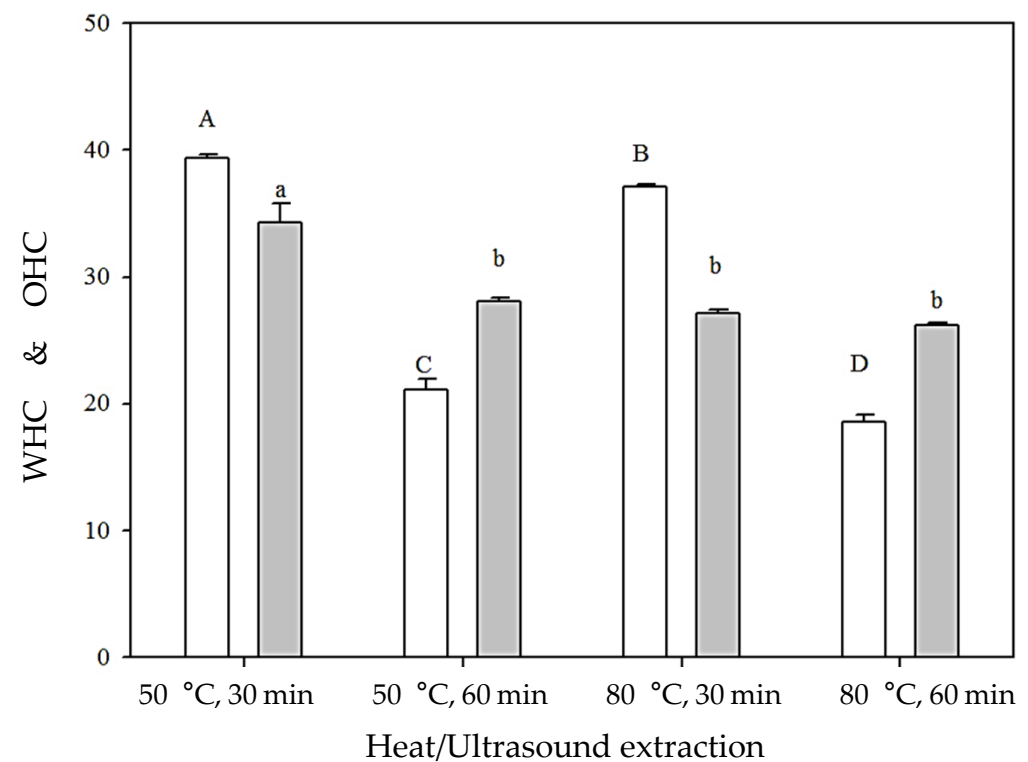

Figure 5. The water holding capacity (WHC, $\square$ ) and oil holding capacity $(\mathrm{OHC}, \square$ ) of chia seed mucilage extracted by ultrasound in combination with heat. Error bars represent standard deviations. Means with different superscript capital letters and lowercase letters denote significant difference among WHC and OHC ( $p<0.05)$, respectively.

It should be noted that polysaccharide has the ability to retain water. In our study, chia seed mucilage extracted at $50{ }^{\circ} \mathrm{C}$ for $30 \mathrm{~min}$ had the highest carbohydrate content (Table 3), i.e., polysaccharide content, resulting in higher WHC. Moreover, the polysaccharide in mucilage might undergo partial degradation when the time of heat/ultrasound extraction was long [31]. This might affect its ability of water retention, leading to a lower WHC of mucilage prepared with heat/ultrasound extraction for $60 \mathrm{~min}$ in this study. On the other hand, chia seed mucilage seems to possess adequate oil absorption capacity, and this could be due to the protein content. Proteins have exposed hydrophobic sites that interact with lipids and increase $\mathrm{OHC}$.

\subsubsection{Emulsifying Property}

Emulsifying ability measures the ability of an emulsifying agent to facilitate solubilization or dispersion of two immiscible liquids, whereas emulsion stability measures its resistance to rupture over time. Emulsification leads to an increase in turbidity of the solution, which could be measured by a spectrophotometer at a wavelength of $500 \mathrm{~nm}$. Therefore, the higher the absorbance of the emulsion, the higher is the emulsifying ability of the emulsifier [32].

The absorbance at $500 \mathrm{~nm}$ and emulsifying stability index (ESI) of chia seed mucilage extracted by ultrasound in combination with heat at different concentrations are presented 
in Figure 6. Both absorbance and ESI of chia seed mucilages increased on increasing the concentration. Moreover, both absorbance and ESI of chia seed mucilage extracted at $50{ }^{\circ} \mathrm{C}$ were significantly higher than that of mucilage extracted at $80{ }^{\circ} \mathrm{C}$. The above results indicate that the mucilage extracted at $50{ }^{\circ} \mathrm{C}$ with a higher concentration had the best emulsifying ability and stability. Garti and Leser [33] and Timilsena et al. [8] mentioned that the hydrophilic polysaccharides stabilized emulsions by increasing the viscosity of the continuous phase, where the movement of oil droplets was reduced by decreasing particle coalescence. In addition, the polysaccharides with traces of protein exhibit high surface activity (e.g., gum Arabic and guar gum) and the anionic polysaccharides might also possess surface activity due to their anionic nature, resulting in an increase in charge on the oil droplets and causing electrostatic repulsion. Chia seed mucilage is an anionic polysaccharide with a significant amount of uronic acids (glucuronic acid and galacturonic acid) [8]. Moreover, in our study, the mucilage extracted at $50{ }^{\circ} \mathrm{C}$ comprised about 5.1-5.7\% protein. Accordingly, these mucilages were expected to contribute to the surface activity and stabilization of emulsions. However, the mucilage extracted at $80{ }^{\circ} \mathrm{C}$ had a lesser amount of polysaccharide, and this might cause reduction in the stability of the emulsions.
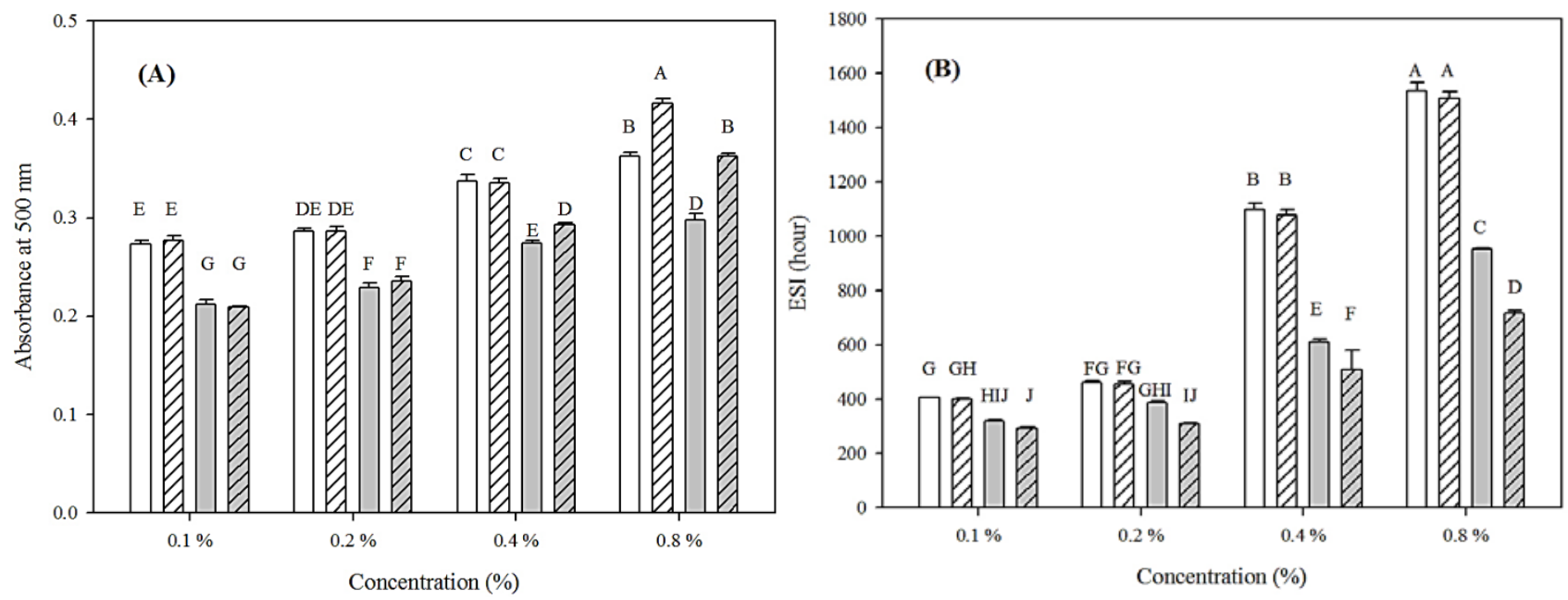

Figure 6. The (A) absorbance at $500 \mathrm{~nm}$ and (B) emulsifying stability index (ESI) of chia seed mucilage extracted by ultrasound in combination with heat at different concentrations. Error bars represent standard deviations. Means with different superscript capital letters denote significant

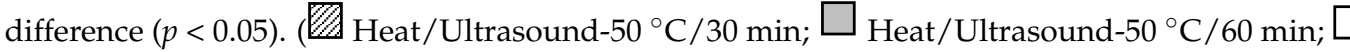

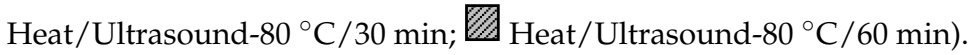

\subsubsection{Flow Behavior}

Typical flow curves for different concentrations of xanthan gum and chia seed mucilages extracted by ultrasound in combination with heat are shown in Figure 7 . The unpurified mucilage samples at a concentration of $0.25 \%$ exhibited a nearly Newtonian-like behavior, while these samples demonstrated a non-Newtonian, shear-thinning (pseudoplastic) behavior with increasing concentration (Figure 7A-D). Furthermore, clear shearthinning behavior was observed with xanthan gum (Figure 7F) and purified mucilage sample (Figure $7 \mathrm{E}$ ) at a concentration of $0.25 \%$. Shear stress tended to approach a limiting constant value as the shear rate toward zero, indicating that the xanthan gum and purified mucilage sample exhibited a finite magnitude of yield stress. Similar curves were obtained at other concentrations. 

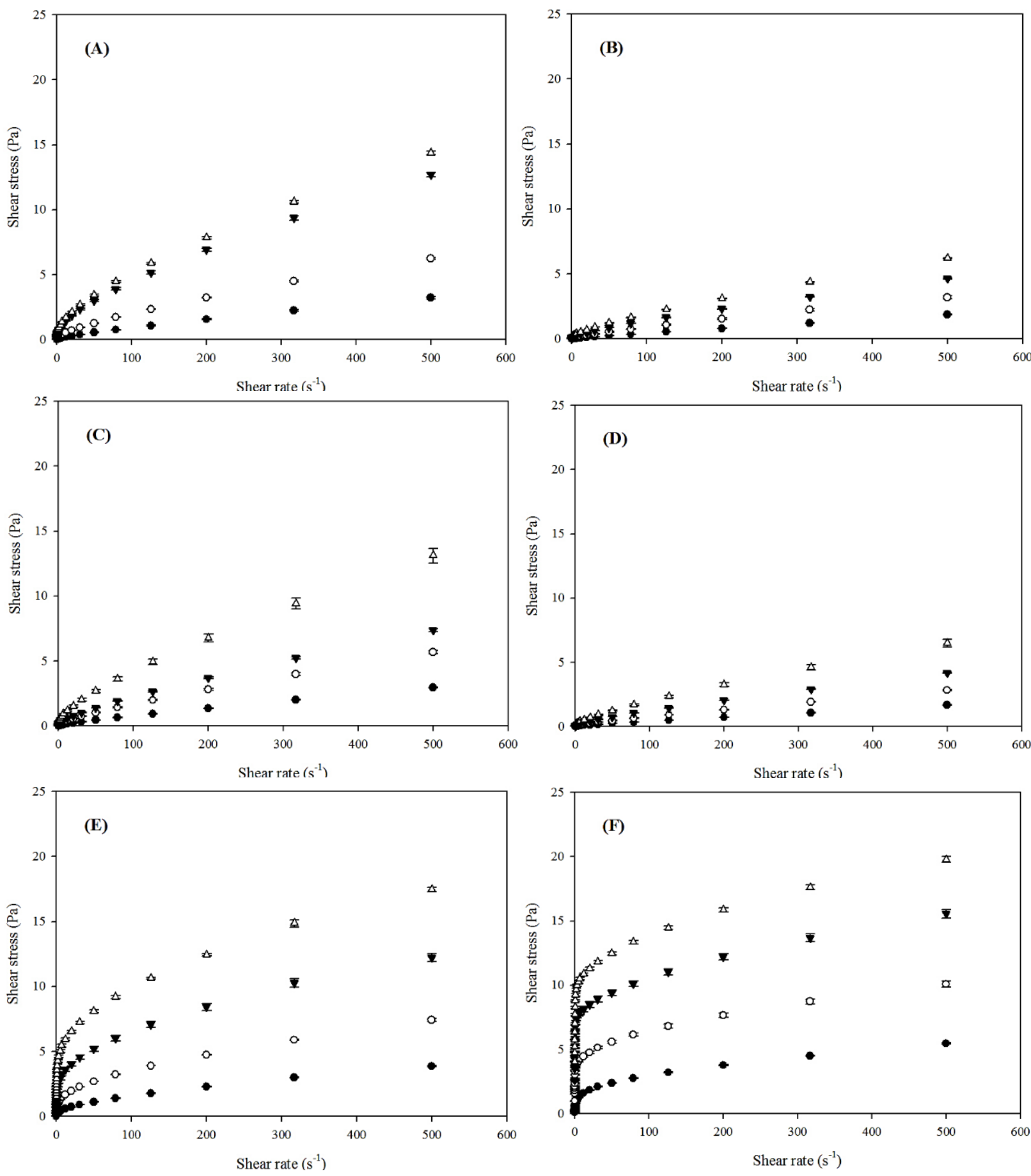

Figure 7. Shear stress as a function of shear rate for different concentrations of xanthan gum and chia seed mucilage extracted by ultrasound in combination with heat. (A) Heat/Ultrasound- $50{ }^{\circ} \mathrm{C} / 30 \mathrm{~min}$; (B) Heat/Ultrasound-50 ${ }^{\circ} \mathrm{C} / 60 \mathrm{~min}$; (C) Heat/Ultrasound- $80{ }^{\circ} \mathrm{C} / 30 \mathrm{~min}$; (D) Heat/Ultrasound$80{ }^{\circ} \mathrm{C} / 60 \mathrm{~min}$; (E) Heat/Ultrasound-50 ${ }^{\circ} \mathrm{C} / 60 \mathrm{~min}$ with purification; (F) xanthan gum. Error bars represent standard deviations $(\bullet 0.25 \%, \bigcirc 0.5 \%, \nabla 0.75 \%, \triangle 1 \%)$.

The apparent viscosity of xanthan gum and chia seed mucilages extracted by ultrasound in combination with heat at various concentrations are plotted in Figure 8 as a function of shear rate. The apparent viscosity of mucilage samples and xanthan gum decreased as the shear rate increased, indicating their shear-thinning behavior, except for the unpurified mucilage samples at a concentration of $0.25 \%$. Capitani et al. [13] mentioned that 
as shear rate increased, the randomly dispersed chains of polymer molecules (e.g., xanthan gum) became aligned in the direction of the flow, and resulted in less interaction among adjacent polymer chains, leading to the dispersions with lower viscosity. On the other hand, the apparent viscosity of dispersions increased with the increase in mucilage and xanthan gum concentration. The higher total solid content in the dispersion causes an increase in the restriction of intermolecular motion by hydrodynamic forces and the formation of an interfacial film, resulting in a higher viscosity [13].
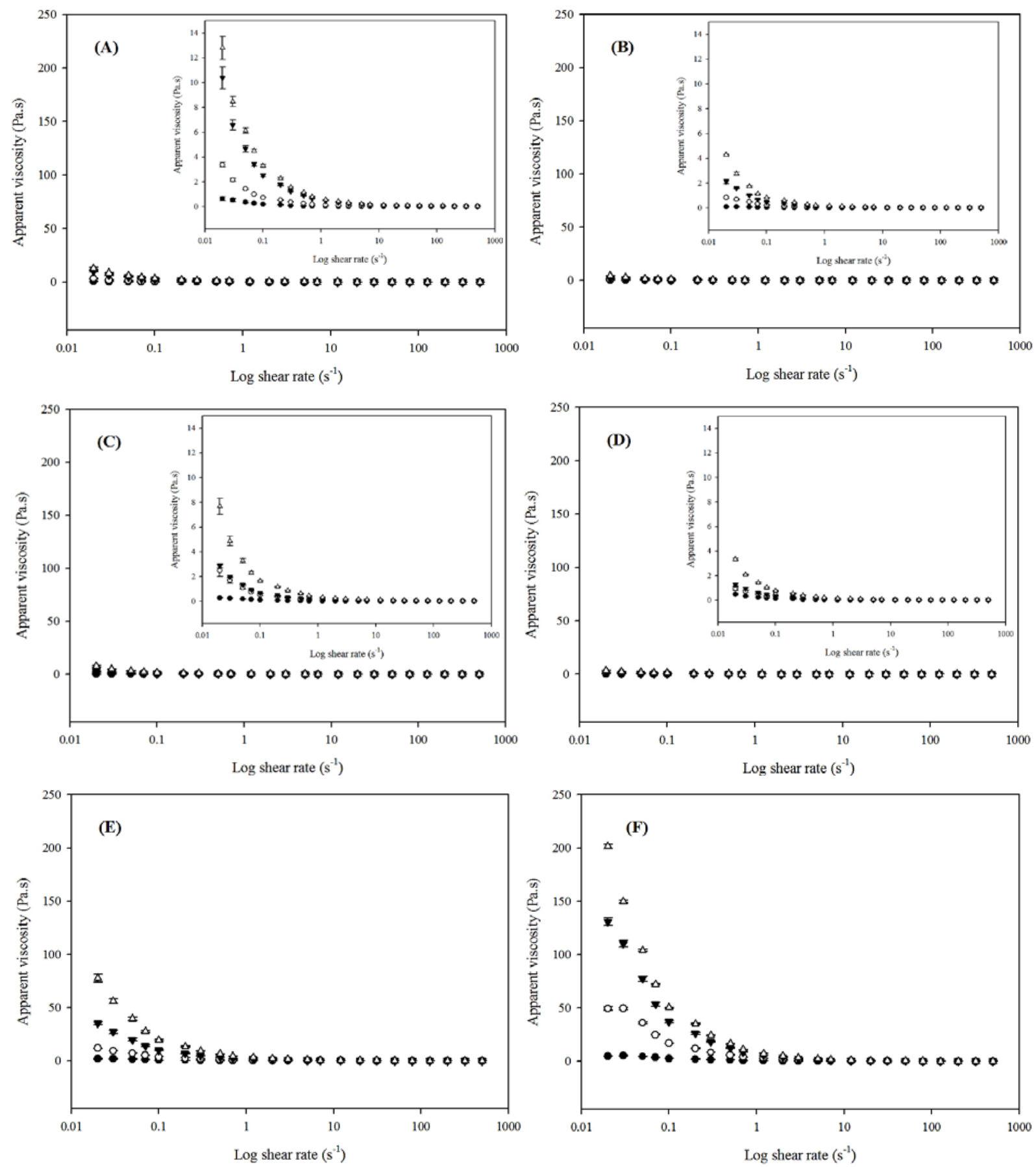

Figure 8. Apparent viscosity as a function of shear rate for different concentrations of xanthan gum and chia seed mucilage extracted by ultrasound in combination with heat. (A) Heat/ Ultrasound-50 ${ }^{\circ} \mathrm{C} / 30 \mathrm{~min}$; (B) Heat/Ultrasound-50 ${ }^{\circ} \mathrm{C} / 60 \mathrm{~min}$; (C) Heat/Ultrasound-80 ${ }^{\circ} \mathrm{C} /$ $30 \mathrm{~min}$; (D) Heat/Ultrasound-80 ${ }^{\circ} \mathrm{C} / 60 \mathrm{~min}$; (E) Heat/Ultrasound $-50{ }^{\circ} \mathrm{C} / 60 \mathrm{~min}$ with purification; (F) xanthan gum. Error bars represent standard deviations $(\bullet 0.25 \%, \bigcirc 0.5 \%, \nabla 0.75 \%, \triangle 1 \%)$. 
The consistency index $(\mathrm{k})$, flow behavior index $(\mathrm{n})$, and yield stress $\left(\sigma_{\mathrm{y}}\right)$ values obtained by fitting the Herschel-Bulkely model to the shear stress versus shear rate data as a function of mucilage and xanthan gum concentration are summarized in Table 4 . The values of $n$ for all the samples were lower than 1 , thus confirming the shear-thinning nature of the dispersions for the studied conditions. However, the $n$ values of mucilages prepared with heat/ultrasound extraction at both $50{ }^{\circ} \mathrm{C}$ and $80{ }^{\circ} \mathrm{C}$ for $60 \mathrm{~min}$ at lower concentration were close to 1 , indicating that these dispersions tended to be closer to the Newtonian flow. The purified mucilage and xanthan gum had lower $n$ value. Generally, the $n$ value decreased with increasing concentration for all samples, indicating an increase in pseudoplasticity.

Table 4. Flow behavior of xanthan gum and chia seed mucilages extracted by ultrasound in combination with heat.

\begin{tabular}{|c|c|c|c|c|c|}
\hline $\begin{array}{c}\text { Heat/Ultrasound } \\
\text { Extraction Conditions }\end{array}$ & Purification & Concentration $(\%)$ & $\begin{array}{l}\text { Yield Stress }\left(\sigma_{y}\right) \\
\qquad(\mathrm{mPa})\end{array}$ & $\begin{array}{l}\text { Consistency Index }(\mathbf{k}) \\
\left(\mathrm{mPa} \times \mathrm{s}^{\mathrm{n}}\right)\end{array}$ & $\begin{array}{l}\text { Flow Behavior } \\
\text { Index (n) }\end{array}$ \\
\hline \multirow[t]{4}{*}{$50^{\circ} \mathrm{C} / 30 \mathrm{~min}$} & \multirow[t]{4}{*}{ No } & 0.25 & $23 \pm 4^{\mathrm{G}}$ & $23 \pm 1 \mathrm{~J}$ & $0.794 \pm 0.004^{\mathrm{CD}}$ \\
\hline & & 0.5 & $86 \pm 2^{\mathrm{FG}}$ & $70 \pm 2 \mathrm{HIJ}$ & $0.721 \pm 0.004 \mathrm{H}$ \\
\hline & & 0.75 & $300 \pm 9 \mathrm{DE}$ & $202 \pm 11^{\mathrm{HI}}$ & $0.661 \pm 0.007^{\mathrm{I}}$ \\
\hline & & 1 & $385 \pm 11^{\mathrm{D}}$ & $226 \pm 6^{\mathrm{GH}}$ & $0.662 \pm 0.003^{I}$ \\
\hline \multirow[t]{4}{*}{$50^{\circ} \mathrm{C} / 60 \mathrm{~min}$} & \multirow[t]{4}{*}{ No } & 0.25 & $9 \pm 1^{\mathrm{G}}$ & $6 \pm 0 \mathrm{~J}$ & $0.911 \pm 0.003^{\mathrm{A}}$ \\
\hline & & 0.5 & $29 \pm 3^{G}$ & $22 \pm 2^{\mathrm{J}}$ & $0.800 \pm 0.009^{C}$ \\
\hline & & 0.75 & $60 \pm 3^{\mathrm{FG}}$ & $39 \pm 2^{\mathrm{IJ}}$ & $0.766 \pm 0.008^{\mathrm{EFG}}$ \\
\hline & & 1 & $106 \pm 1^{\mathrm{FG}}$ & $58 \pm 1^{\mathrm{HIJ}}$ & $0.749 \pm 0.003^{\mathrm{FG}}$ \\
\hline \multirow[t]{4}{*}{$80^{\circ} \mathrm{C} / 30 \mathrm{~min}$} & \multirow[t]{4}{*}{ No } & 0.25 & $16 \pm 1^{\mathrm{G}}$ & $16 \pm 1^{\mathrm{J}}$ & $0.839 \pm 0.004^{\mathrm{B}}$ \\
\hline & & 0.5 & $69 \pm 9^{\mathrm{FG}}$ & $47 \pm 2^{\mathrm{IJ}}$ & $0.770 \pm 0.062^{\mathrm{EF}}$ \\
\hline & & 0.75 & $83 \pm 0$ FG & $70 \pm 1 \mathrm{HIJ}$ & $0.747 \pm 0.003^{G}$ \\
\hline & & 1 & $204 \pm 13^{\mathrm{EF}}$ & $148 \pm 7 \mathrm{HIJ}$ & $0.718 \pm 0.003^{\mathrm{H}}$ \\
\hline \multirow[t]{4}{*}{$80^{\circ} \mathrm{C} / 60 \mathrm{~min}$} & \multirow[t]{4}{*}{ No } & 0.25 & $25 \pm 3^{G}$ & $6 \pm 1 \mathrm{~J}$ & $0.910 \pm 0.019^{\mathrm{A}}$ \\
\hline & & 0.5 & $46 \pm 11$ FG & $16 \pm 0 \mathrm{~J}$ & $0.833 \pm 0.005^{\text {В }}$ \\
\hline & & 0.75 & $43 \pm 4^{G}$ & $34 \pm 1^{\mathrm{IJ}}$ & $0.772 \pm 0.006^{\mathrm{DE}}$ \\
\hline & & 1 & $98 \pm 3^{\mathrm{FG}}$ & $59 \pm 1 \mathrm{HIJ}$ & $0.752 \pm 0.004$ EFG \\
\hline \multirow[t]{4}{*}{$50^{\circ} \mathrm{C} / 60 \mathrm{~min}$} & \multirow[t]{4}{*}{ Yes } & 0.25 & $87 \pm 5^{\mathrm{FG}}$ & $118 \pm 1^{\mathrm{HIJ}}$ & $0.555 \pm 0.003^{\mathrm{J}}$ \\
\hline & & 0.5 & $352 \pm 4 \mathrm{DE}$ & $397 \pm 7^{\mathrm{G}}$ & $0.459 \pm 0.005^{\mathrm{K}}$ \\
\hline & & 0.75 & $873 \pm 35^{C}$ & $981 \pm 59^{\mathrm{E}}$ & $0.390 \pm 0.007^{\mathrm{L}}$ \\
\hline & & 1 & $1685 \pm 93^{\mathrm{A}}$ & $1684 \pm 19^{\mathrm{D}}$ & $0.355 \pm 0.002 \mathrm{M}$ \\
\hline \multirow{4}{*}{\multicolumn{2}{|c|}{ Xanthan gum }} & 0.25 & $36 \pm 0^{\mathrm{G}}$ & $651 \pm 10^{\mathrm{F}}$ & $0.336 \pm 0.000^{\mathrm{M}}$ \\
\hline & & 0.5 & $842 \pm 53^{C}$ & $2140 \pm 13^{C}$ & $0.224 \pm 0.004^{\mathrm{N}}$ \\
\hline & & 0.75 & $1074 \pm 62^{B}$ & $5002 \pm 178^{\mathrm{B}}$ & $0.156 \pm 0.002^{\mathrm{O}}$ \\
\hline & & 1 & $1138 \pm 153^{\mathrm{B}}$ & $6982 \pm 115^{\mathrm{A}}$ & $0.144 \pm 0.003^{\mathrm{O}}$ \\
\hline
\end{tabular}

Values are mean \pm standard deviation. Different superscript capital letters within a column indicate significant differences $(p<0.05)$.

The yield stress of a material is defined as the minimum shear stress that must be applied to a material to induce flow [34]. The mucilage samples and xanthan gum under all test conditions were characterized by yield stress. Higher yield stress values were observed at higher concentration of dispersions, while the yield stress of mucilages prepared with heat/ultrasound extraction at both $50^{\circ} \mathrm{C}$ and $80^{\circ} \mathrm{C}$ for $60 \mathrm{~min}$ was not significantly different among different concentrations.

The consistency index $(\mathrm{k})$ indicates the viscous nature of the dispersion system. The purified mucilage and xanthan gum had higher $\mathrm{k}$ value. As compared to the HerschelBulkely parameters of unpurified mucilage to that of purified mucilage, the protein content might affect the flow behavior of mucilage. The molecules of polysaccharide in purified mucilage could have a better interaction, leading to a higher viscosity. The flow behavior of purified mucilage was in good agreement with the data presented by Capitani et al. [13] and Goh et al. [14]. The $\mathrm{k}$ value of mucilage prepared with heat/ultrasound extraction at $50{ }^{\circ} \mathrm{C}$ for $30 \mathrm{~min}$, purified mucilage, and xanthan gum increased with concentration, indicating an increase in apparent viscosity at a higher concentration. The above changes were more pronounced in the purified mucilage and xanthan gum. However, for mucilages prepared 
with heat/ultrasound extraction at $50{ }^{\circ} \mathrm{C}$ for $60 \mathrm{~min}$ and at $80{ }^{\circ} \mathrm{C}$ for both 30 and $60 \mathrm{~min}$, their $\mathrm{k}$ values were similar and almost unaffected by concentration. It is clear that extraction time had a negative effect on the k value; meanwhile, the time effect was greater than the temperature effect. Overall, ultrasound treatment led to a decrease in $\mathrm{k}$ and increase in $\mathrm{n}$, indicating that ultrasound forced the mucilages toward a more Newtonian-like behavior and reduced their viscosity. We believe that partial degradation of polysaccharide and protein content in mucilage might have contributed to these changes.

\subsubsection{Phase Behavior}

Polysaccharides are often added to dairy products and other foods beverages containing proteins as stabilizers to enhance viscosity and alter textural characteristics; meanwhile, the phase behavior of protein-polysaccharide mixtures contribute significantly to the stability, structural, rheological, and textural characteristics of food products. In this study, phase diagrams were determined to investigate the concentration levels at which unpurified or purified mucilages in mixtures with different proteins exhibit compatibility (co-solubility) or incompatibility (phase-separation) (Figure 9). The solid curve represents the binodal, which defines the boundary between miscible and immiscible mixtures. Therefore, the area below the binodal indicates the concentration levels at which the mucilage/protein mixtures are at equilibrium, whereas the area above the binodal represents the concentration zones where phase separation occurs.
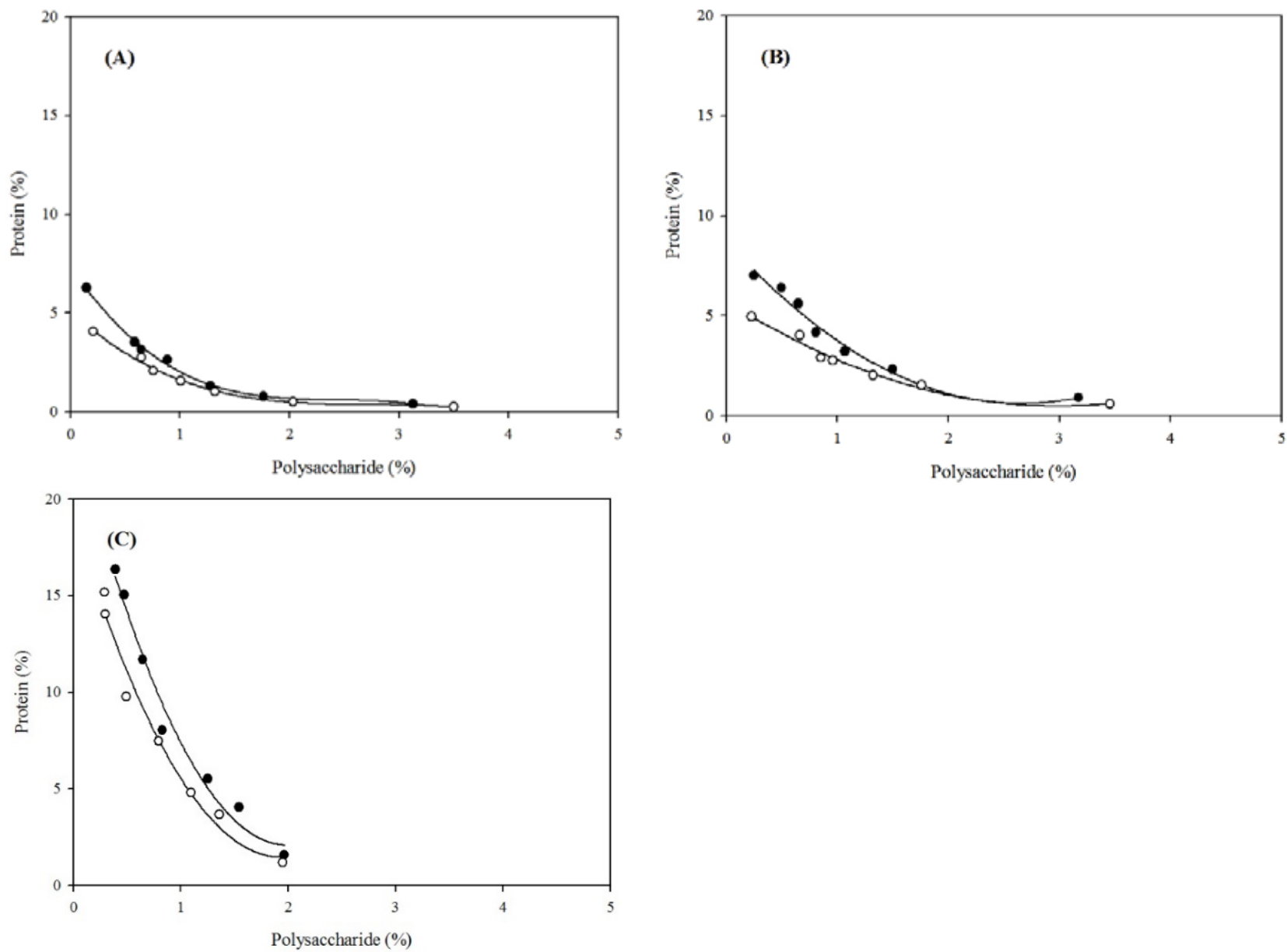

Figure 9. Phase diagram of binary mixtures of chia seed mucilage ( $\bullet$ unpurified, $\bigcirc$ purified) and different proteins: (A) soy protein isolate, (B) sodium caseinate, (C) whey protein isolate. The points in the figure are experimental values. The line is the predicted value of $Y$ in the equation of $\mathrm{Y}=\mathrm{Y}_{0}+\mathrm{A} \times \exp ^{(-\mathrm{R} 0 \times \mathrm{X})}$. The values of $\mathrm{Y}_{0}, \mathrm{~A}, \mathrm{R}_{0}$, and determination coefficient are shown in Supplementary. 
At low concentrations of mucilage and protein, the homogeneous protein-polysaccharide mixtures were formed (stable region), which indicate the compatibility of proteins and mucilage (Figure 9). As the concentration of proteins increased, phase separation was induced. Furthermore, the compatibility region of un-purified mucilage was more than that of purified mucilage. The binodal of mucilage/SPI and mucilage/Na-caseinate mixtures were closer to both axes than that of mucilage/WPI, suggesting that the compatibility of mucilage with WPI increased. Both protein and mucilage used in this study were negatively charged at pH 7.0; thus, there was no complex formation. According to Doublier et al. [35], the mechanism of phase separation of mucilage/WPI was due to thermodynamic incompatibility (excluded volume effect) since the total biopolymer concentration for phase separation was above $4 \%$. On the other hand, the phase separation of mucilage/SPI and mucilage/Na-caseinate was through the depletion flocculation mechanism because these proteins were particle-like and large, and the total biopolymer concentration for phase separation was low.

\section{Conclusions}

A combination of ultrasound and heat is able to assist the separation of mucilage from chia seed coat and improve extraction efficiency. Time is an important variable of the ultrasonic process, affecting the extraction of chia seed mucilage. The mucilage prepared with heat/ultrasound extraction at $50{ }^{\circ} \mathrm{C}$ and $80^{\circ} \mathrm{C}$ for $60 \mathrm{~min}$ had the best yield. Increase in extraction temperature did not increase the yield of mucilage. The mucilage prepared with heat/ultrasound extraction at $50{ }^{\circ} \mathrm{C}$ for $30 \mathrm{~min}$ and $60 \mathrm{~min}$ had the best technological properties. The amount of protein in the heat/ultrasound extracted mucilage diversified its technological property. Moreover, the mixture of mucilage and WPI had better miscibility.

Supplementary Materials: The following are available online at https:/ / www.mdpi.com/article/10 $.3390 /$ pr10030519/s1, Table S1: The exponential equation of phase diagram of binary mixtures of chia seed mucilage and food proteins.

Author Contributions: Conceptualization, M.-I.K.; methodology, W.-H.W. and C.-P.L.; validation, M.-I.K. and C.-P.L.; formal analysis, W.-H.W.; writing—original draft preparation, W.-H.W.; writing-review and editing, M.-I.K.; project administration, M.-I.K. All authors have read and agreed to the published version of the manuscript.

Funding: This research received no external funding.

Institutional Review Board Statement: Not applicable.

Informed Consent Statement: Not applicable.

Data Availability Statement: All data that support the findings of this study are included within the article.

Acknowledgments: The authors would like to thank Jen-Yu Tseng from Texture Maker Enterprise Co., Ltd. for the generous supply of chia seeds.

Conflicts of Interest: The authors declare no conflict of interest.

\section{References}

1. Muñoz, L.A.; Cobos, A.; Diaz, O.; Aguilera, J.M. Chia seed (Salvia hispanica): An ancient grain and a new functional food. Food. Rev. Int. 2013, 29, 394-408. [CrossRef]

2. Bushway, A.A.; Belyea, P.R.; Busheay, R.J. Chia seed as a source of oil, polysaccharide, and protein. J. Food Sci. 1981, 46, 1349-1356. [CrossRef]

3. Marcinek, K.; Krejpcio, Z. Chia seeds (Salvia hispanica): Health promoting properties and therapeutic applications-A review. Rocz. Państwowego Zakładu Hig. 2017, 68, 123-129.

4. Ali, N.M.; Yeap, S.K.; Ho, W.Y.; Beh, B.K.; Tan, S.W.; Tan, S.G. The promising future of chia, Salvia hispanica L. J. Biotechnol. Biomed. 2012, 2012, 171956.

5. Rabail, R.; Khan, M.R.; Mehwish, H.M.; Rajoka, M.S.R.; Lorenzo, J.M.; Kieliszek, M.; Khalid, A.R.; Shabbir, M.A.; Aadil, R.M. An overview of chia seed (Salvia hispanica L.) bioactive peptides' deriation and utilization as an emerging nutraceutical food. Font. Biosci. 2021, 26, 643-654. 
6. Segura-Campos, M.R.; Ciau-Solís, N.; Rosado-Rubio, G.; Chel-Guerrero, L.; Betancur-Ancona, D. Chemical and functional properties of chia seed (Salvia hispanica L.) gum. Int. J. Food Sci. 2014, 2014, 241053. [CrossRef] [PubMed]

7. Lin, K.Y.; Daniel, L.R.; Whistler, R.L. Structure of chia seed polysaccharide exudate. Carbohydr. Polym. 1994, 23, 13-18. [CrossRef]

8. Timilsena, Y.P.; Adhikari, R.; Kasapis, S.; Adhikari, B. Molecular and functional characteristics of purified gum from Australian chia seeds. Carbohydr. Polym. 2016, 136, 128-136. [CrossRef]

9. Muñoz, L.A.; Cobos, A.; Diaz, O.; Aguilera, J.M. Chia seeds: Microstructure, mucilage extraction and hydration. J. Food Eng. 2012, 108, 216-224. [CrossRef]

10. Orifici, S.C.; Capitani, M.I.; Tomás, M.C.; Nolasco, S.M. Optimization of mucilage extraction from chia seeds (Salvia hispanica L.) using response surface methodology. J. Sci. Food Agric. 2018, 98, 4495-4500. [CrossRef]

11. Campos, B.E.; Ruivo, T.D.; Scapim, M.R.S.; Madrona, G.S.; Bergamasco, R.C. Optimization of the mucilage extraction process from chia seeds and application in ice cream as a stabilizer and emulsifier. LWT Food Sci. Technol. 2016, 65, 874-883. [CrossRef]

12. Coorey, R.; Tjoe, A.; Jayasena, V. Gelling properties of chia seed and flour. J. Food Sci. 2014, 79, E859-E866. [CrossRef] [PubMed]

13. Capitani, M.I.; Corzo-Rios, L.J.; Chel-Guerrero, L.A.; Betancur-Ancona, D.A.; Nolasco, S.M.; Tomás, M.C. Rheological properties of aqueous dispersions of chia (Salvia hispanica L.) mucilage. J. Food Eng. 2015, 149, 70-77. [CrossRef]

14. Goh, K.K.T.; Matia-Merino, L.; Chiang, J.H.; Quek, R.; Soh, S.J.B.; Lentle, R.G. The physicochemical properties of chia seed polysaccharide and its microgel dispersion rheology. Carbohydr. Polym. 2016, 149, 297-307. [CrossRef] [PubMed]

15. Tavares, L.S.; Junqueira, L.A.; de Qliveira Guimaraes, I.C.; de Resende, J.V. Cold extraction method of chia seed mucilage (Salvia hispanica L.): Effect on yield and rheological behavior. J. Food Sci. Technol. 2018, 55, 457-466. [CrossRef] [PubMed]

16. Marin, F.M.; Acevedo, M.J.; Tamez, R.M.; Nevero, M.J.; Garay, A.L. Method for Obtaining Mucilage from Salvia hispanica L. WO/2008/0044908c, 29 May 2008.

17. Kentish, S.; Feng, H. Applications of power ultrasound in food processing. Annu. Rev. Food Sci. Technol. 2014, 5, 263-284. [CrossRef]

18. Brummer, Y.; Cui, W.; Wang, Q. Extraction, purification and physicochemical characterization of fenugreek gum. Food Hydrocoll 2003, 17, 229-236. [CrossRef]

19. AOAC internationl. Official Methods of Analysis of AOAC International, 18th ed.; AOAC International: Rockville, MD, USA, 2005.

20. CNS. The National Standards of the Republic of China; Bureau of Standards, Methodology \& Inspection: Taipei, Taiwan, 1984.

21. Timilsena, Y.P.; Adhikari, R.; Kasapis, S.; Adhikari, B. Rheological and microstructural properties of the chia seed polysaccharide. Int. J. Biol. Macromol. 2015, 81, 991-999. [CrossRef]

22. Kontogiorgos, V.; Tosh, S.M.; Wood, P.J. Phase behaviour of high molecular weight oat $\beta$-glucan whey protein isolate binary mixtures. Food Hydrocoll. 2009, 23, 949-956. [CrossRef]

23. Ixtaina, V.Y.; Nolasco, S.M.; Tomás, M.C. Physical properties of chia (Salvia hispanica L.) seeds. Ind. Crops Prod. 2008, 28, $286-293$. [CrossRef]

24. Capitani, M.I.; Ixtaina, V.Y.; Nolasco, S.M.; Tomás, M.C. Microstructure, chemical composition and mucilage exudation of chia (Salvia hispanica L.) nutlets from Argentina. J. Sci. Food Agric. 2013, 93, 3856-3862. [CrossRef] [PubMed]

25. Zia, S.; Khan, M.R.; Shabbir, M.A.; Maan, A.A.; Khan, M.K.I.; Nadeem, M.; Khalil, A.A.; Din, A.; Aadil, M. An inclusive overview of advanced thermal and nonthermal extraction techniques for bioactive compounds in food and food-related matrices. Food Rev. Int. 2020, 1-31. [CrossRef]

26. Farahnaky, A.; Bakhshizadeh-Shirazi, S.H.; Mesbahi, G.H.; Majzoobi, M.; Rezvani, E.; Schleining, G. Ultrasound-assisted isolation of mucilaginous hydrocolloids from Salvia macrosiphon seeds and studying their functional properties. Innov. Food Sci. Emerg. Technol. 2013, 20, 182-190. [CrossRef]

27. Zheng, Q.; Ren, D.; Yang, N.; Yang, X. Optimization for ultrasound-assisted extraction of polysaccharides with chemical composition and antioxidant activity from the Artemisia sphaerocephala Krasch seeds. Int. J. Biol. Macromol. 2016, 91, 856-866. [CrossRef] [PubMed]

28. García-Salcedo, Á.J.; Torres-Vargas, O.L.; del Real, A.; Contreras-Jiménez, B.; Rodriguez-Garcia, M.E. Pasting, viscoelastic, and physicochemical properties of chia (Salvia hispanica L.) flour and mucilage. Food Strcut. 2018, 16, 59-66. [CrossRef]

29. Timilsena, Y.P.; Adhikari, R.; Barrow, C.J.; Adhikari, B. Physicochemical and functional properties of protein isolate produced. Food Chem. 2016, 212, 648-656. [CrossRef]

30. Olivos-Lugo, B.L.; Valdivia-López, M.Á.; Tecante, A. Thermal and physicochemical properties and nutritional value of the protein fraction of mexican chia seed (Salvia hispanica L.). Food Sci. Technol. Int. 2010, 16, 89-96. [CrossRef]

31. Hu, W.; Chen, S.; Wu, D.; Zhu, K.; Ye, Z. Manosonication assisted extraction and characterization of pectin from different citrus peel wastes. Food Hydrocoll. 2021, 121, 106952. [CrossRef]

32. Pearce, K.N.; Kinsella, J.E. Emulsifying properties of proteins: Evaluation of a turbidimetric technique. J. Agricul. Food Chem. 1978, 26, 716-723. [CrossRef]

33. Garti, N.; Leser, M.E. Emulsification properties of hydrocolloids. Polym. Adv. Technol. 2001, 12, 123-135. [CrossRef]

34. Song, K.W.; Kim, Y.S.; Chang, G.S. Rheology of concentrated xanthan gum solutions: Steady shear flow behavior. Fibers Polym. 2006, 7, 129-138. [CrossRef]

35. Doublier, J.L.; Garnier, C.; Renard, D.; Sanchez, C. Protein-polysaccharide interactions. Curr. Opin. Colloid Interface Sci. 2000, 5 , 202-214. [CrossRef] 